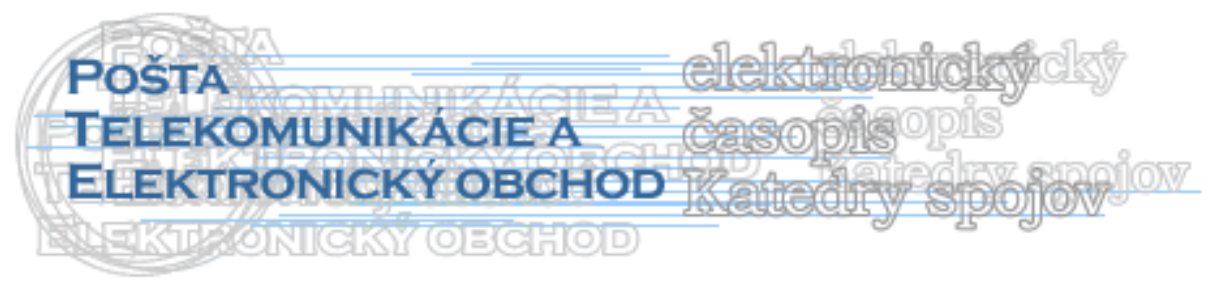

\title{
TECHNOLÓGIE M2M KOMUNIKÁCIE
}

\author{
Juraj Vaculík ${ }^{1}$, Tomáš Korchán ${ }^{2}$
}

\section{Úvod.}

Technológiou označujeme, ktoré umožňujú, aby zariadenia komunikovali s centrálnym serverom bez l'udského zásahu. Ide o vel'mi rýchlo rastúci segment trhu, ktorý je založený na kombinácií niekol'kých technológií - zberu informácií, ich prenosu a spracovaniu.

Pojem M2M (Machine-to-Machine) predstavuje súbor technológií, ktoré umožňujú jednak bezdrôtovým tak aj káblový systémom komunikovat's inými zariadeniami, ktoré majú rovnaké schopnosti. M2M využíva prístroje a koncové prvky, napríklad (napríklad senzor alebo merače) pre zachytenie udalostí (ako je teplota, úroveň zásob a pod.), ktoré sú prenášané prostredníctvom bezdrôtovej, káblovej alebo hybridné siete na aplikáciu, ktorá transformuje zachytené udalosti do zmysluplných informácií (napríklad položky, ktoré sa musia doplnit', informácia o zmene teploty a d'alšie). Táto oblast' na nazýva telemetria čo si je možné predstavit' ako nízkoúrovňový jazyk, ktorý používajú prístroje $\mathrm{v}$ komunikácii $\mathrm{s}$ ostatnými prvkami. Takáto komunikácia sa pôvodne dosahovala tým, že vzdialené prístroje a senzory $\mathrm{v}$ sieti prenášali informácie spät' do centrálneho miesta pre analýzu a následne presmerované do hierarchicky vyššieho systému, ako je osobný počítač pre riadenie. V technológii M2M sa stretávajú tri odbory - výpočtová technika, elektronika a telekomunikácie a vytvárajú špecifický ekosystém, ktorý sa niekedy označuje aj termínom Pervasive Internet (všadeprítomný internet).

Bezdrôtové komunikačné technológie predstavujú jednu z rýchlo sa rozvíjajúcich oblastí telekomunikačných technológií. Vznik bezdrôtovej komunikácie spadá do obdobia na prelome 19. a 20. storočia, kedy taliansky fyzik G. M . Marconi uskutočňoval svoje pokusy s rádiovým prenosom. V roku 1896 si podal Marconi v Londýne patent na bezdrôtový telegraf. Ďalej sa bezdrôtová komunikácia používa hlavne k prenosu hlasu a obrazu, či už v analógovej alebo digitálnej podobe. Aplikáciou technológie, ktorá dovol'uje využit' UHF a mikrovlnné pásma, dochádza k rozvoju nízko rýchlostných a vysoko rýchlostných bezdrôtových komunikácií a bezdrôtových sietí. "Bezdrôtové technológie predstavujú systémy, zariadenia a prostriedky, ktoré eliminujú káblové vedenie a súčasne zachovávajú rovnaké služby." Medzi základné technológie v tejto oblasti patria technológie Blue Tooth, Wi-Fi, RFID a ZigBee.

\footnotetext{
${ }^{1}$ doc. Ing. Juraj Vaculík, PhD., Žilinská univerzita, fakulta PEDAS, Katedra spojov, mail:juvac@fpedas.uniza.sk

${ }^{2}$ Ing. Tomáš Korchán, Žilinská univerzita, Katedra spojov
} 


\section{Technológia ZigBee}

Komunikačná technológia ZigBee predstavuje nízko rýchlostný komunikačný štandard bezdrôtovej komunikácie, zameraný predovšetkým na oblast' automatizácie a riadiacej techniky. Ide o bezdrôtovú komunikačnú technológiu schválenú ako medzinárodný štandard nadnárodnej organizácie ZigBee Alliance a štandardizačnej organizácie IEEE, označovaný tiež ako IEEE 802.15.4.

Štandard ZigBee v súčasnej dobe patrí medzi nové, špecifikácia bola vydaná v roku 2004, perspektívne komunikačné technológie, ktorá sa snaží vyplnit' medzeru medzi rozšírenými technológiami Wi-Fi a Bluetooth. Je tu však medzera v podobe vel'kej skupiny aplikácií, pre ktoré nie sú Bluetooth ani Wi-Fi, prípadne IrDA ideálnym riešením, aj ked' sa dajú použit'. Čiže nemá pôsobit' ako priama konkurencia už zavedených komunikačných štandardov typu Bluetooth, ale naopak ako ich doplnok, ktorý má rozšírit' oblast' nasadenia.

ZigBee je jednoduchý bezdrôtový komunikačný štandard, kde na prenos dát sa používa nelicencované frekvenčné pásmo $2,4 \mathrm{GHz}$ a umožňuje vzájomnú komunikáciu mnohých zariadení na vzdialenosti desiatok metrov. Vd’aka nízkym nárokom na hardware a nízkej spotrebe vysielača a prijímača nachádza uplatnenie $v$ oblasti riadenia budov, spotrebnej elektroniky a priemyslu, napr. v podobe batériovo napájaných bezdrôtových senzorov.

\section{1. Špecifikácia rádiovej časti štandardu}

Štandard ZigBee je založený na využití fyzickej a linkovej vrstvy podl'a medzinárodného štandardu IEEE 802.15.4. Bolo pre neho definovaných niekol'ko rádiových pásiem, aby bol akceptovatel'ný $\mathrm{v}$ rôznych krajinách $\mathrm{s}$ odlišnými predpismi a kritériami. Základným problémom pri definícii rádiových pásiem sú predovšetkým rozdiely v organizácii rádiových pásiem $\mathrm{v}$ Amerike a na európskom kontinente. Aby sa štandard mohol uplatnit' v oboch lokalitách, sú pre neho definované tri rádiové pásma (obr. 1):

- globálne použitie: pásmo ISM 2,4 GHz s 16 kanálmi, prenosová rýchlost' 250kbps;

- Amerika a Austrália: pásmo $950 \mathrm{MHz}$ s 10 kanálmi, prenosová rýchlost’ 40kbps;

- Európa: pásmo $868 \mathrm{MHz}$ s jedným kanálom, prenosová rýchlost'20kbps.

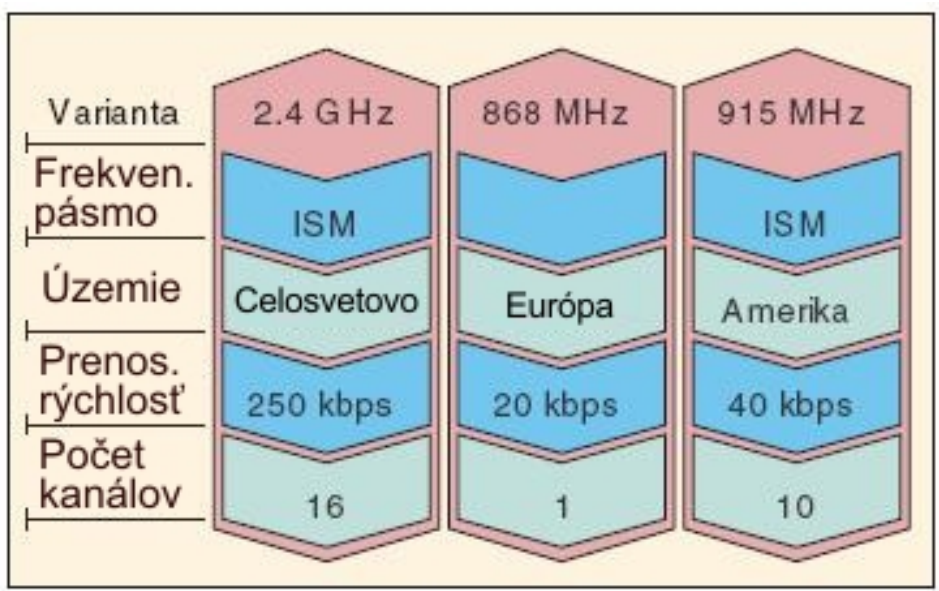

Obr. 1 - Rádiové pásma využívané ZigBee

Technológia je založená na implementácii prístupovej metódy CSMA/CA k fyzickému médiu, čo znamená, že vlastná rádiová čast' štandardu IEEE 802.15.4 tejto metódy využíva na úrovni fyzickej a linkovej vrstvy komunikačného modelu. Vlastný štandard IEEE 802.15.4 
definuje komplexný komunikačný protokol, ktorý je založený na prenose dátových rámcov. Používajú sa štyri typy komunikačných rámcov využívané bud' pre prenos užitočných dátových informácií, alebo $\mathrm{k}$ režijným účelom súvisiacich so zostavením, správou a riadením siete:

- Data Frame - rámec s dížkou užitočných dát 104 byte slúži pre prenos užitočnej informácie pre všetky dátové prenosy v kontexte štandardu;

- Acknowledgemnt Frame - rámec slúži pre prenos potvrdzujúcej informácie; je využitel'ný iba na úrovni MAC pre potvrdzujúcu komunikáciu a je vysielaný v tzv. „mŕtvom čase“ ihned” po prenose paketu;

- MAC Command Frame - rámec slúži k centralizovanému konfigurovaniu, nastaveniu a riadeniu klientskych zariadení v sieti ZigBee;

- Beacon Frame - rámec slúži k synchronizácii zariadení v sieti a je hlavne využívaný pri konfigurácii siete v móde beacon enable, v ktorom umožňuje uvádzat' klientske zariadenia do spánkových režimov s extrémne zníženou spotrebou.

$\mathrm{Na}$ základe časovej synchronizácie medzi centrálnou stanicou a koncovou stanicou dochádza u "uspanej" koncovej stanice k prebudeniu vo vymedzenom časovom intervale a potom sú prenesené užitočné informácie.

\section{Topológia siete ZigBee}

Štandard IEEE 802.15.4 využíva pre adresovanie jednotlivých zariadení binárne adresované kódy, ktoré môžu byt' bud' dlhé (64 bitov) alebo skrátené (16 bitov). Lokálna adresa skráteného adresovaného kódu umožňuje v jednej sieti adresovat' max. 65565 zariadení. Každá zostavená siet' je d’alej identifikovaná 16bitovým identifikátorom PAN ID, ktorý slúži pre rozlíšenie prekrývajúcich sa sietí v prípade, že v jednom priestore dochádza k vytvoreniu a zostaveniu viacerých sietí štandardu IEEE.80.15.4. Každú siet' s jedinečným PAN ID zakladá a spravuje koordinátor (centrálna stanica), pričom ostatné stanice pracujú v móde koncovej stanice. Každá koncová stanica môže byt' konfigurovaná pre funkciu smerovača alebo koncového zariadenia. Podl'a funkčnosti sa zariadenia delia na plne funkčné zariadenia (FFD), ktoré môžu vykonávat' funkciu koordinátora alebo smerovača a na redukované zariadenia (RFD), ktoré môžu fungovat' iba ako koncové zariadenia.

Štandard ZigBee založený na fyzickej a linkovej vrstve IEEE 802.15.4 definuje tri typy siet'ovej topológie (obr. 2).

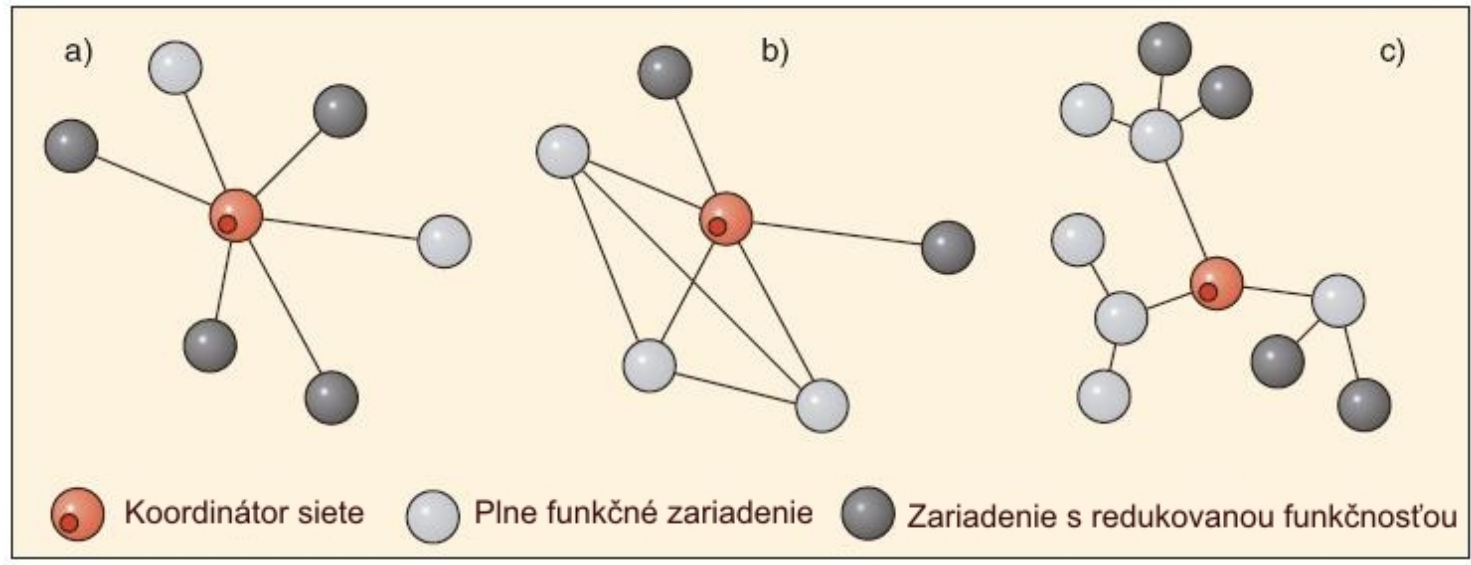

Obr. 2 -Topológia siete ZigBee: typ hviezda (a), siet' (b) a strom (c) 
Základná je topológia typu hviezda (star topology), v ktorej je vždy definované jedno zariadenie, ktoré preberá funkciu koordinátora siete a ostatné zariadenia pôsobia vo funkcii koncových zariadení. V topológii typu strom (tree topology) slúži jedno zariadenie ako koordinátor a ostatné ako koncové zariadenia. Na rozdiel od topológie hviezda však nemusia všetky zariadenia komunikovat' priamo s koordinátorom, ale môžu využit' iné koncové zariadenia v konfigurácii FFD vo funkcii smerovača ako prostredníka. Vd'aka tomu umožňuje uvedená konfigurácia zväčšit' vzdialenost' medzi koncovým zariadením a koordinátorom. Topológia typu siet' (mesh topology) kombinuje vlastnosti oboch predchádzajúcich. Prináša najväčšiu funkčnost', pretože umožňuje zostavit' siet' l'ubovol'ným spôsobom.

\subsubsection{Synchronizácia zariadenia ZigBee}

Synchronizácia jednotlivých zariadení v sieti ZigBee je realizovaná na základe tzv. rámca beacon. Synchronizačnou autoritou je tu vždy koordinátor siete, ktorý v daných okamžikoch vysiela synchronizačné sekvencie, resp. beacon. Sekvencie prijímajú ostatné zariadenia a synchronizujú sa podl'a nich s vysielacou stranou, čiže s koordinátorom. Tento postup umožňuje koncové zariadenia na dlhú, vopred definovanú dobu "uspat"، a značne znížit' tak ich spotrebu. Interval synchronizačných sekvencií môže byt' v rozmedzí 15 ms až približne 15 minút. Pre prenos je možné využit' potom tzv. superrámce, začínajúce práve sekvenciou beacon, po nich nasleduje interval CFP, kedy zariadenie vol'ne sút'aží o prístup $\mathrm{k}$ médiu.

Komunikačný štandard ZigBee je navrhnutý pre aplikácie, v ktorých zariadenia potrebujú vysielat' a prijímat' iba malé objemy dát a kde sa požaduje extrémne nízka spotreba. U koncových zariadení sa predpokladá napájanie z batérie, avšak koordinátor a smerovače by nemali byt' napájané prostredníctvom batérií, pretože funkčnost' siete je na nich závislá.

Pri najjednoduchšej typológii - hviezda a využití technológie beacon sa koncové zariadenie aktivuje po prechode sekvencie beacon a vyšle svoje dáta. Koordinátor dáta príjme a uloží do pamäte. Pri prijatí d'alšej sekvencie beacon indikuje koordinátor ciel'ovému zariadeniu, že má pre neho dáta. Koordinátor pošle dáta vo chvíli, ked' si ich koncové zariadenie vyžiada. Tento spôsob zaručuje najnižšiu spotrebu energie pre koncové zariadenia, ktoré sú väčšinou prepnuté do úsporného režimu. Najväčšie nároky sú kladené na koordinátora, ktorý musí byt' schopný uložit' všetky dáta pre jednotlivé zariadenia.

Prenášané dáta medzi jednotlivými účastníkmi možno zabezpečit’ proti odcudzeniu. Štandard definuje tri režimy a to nezabezpečený prístup, prístup na základe práv a zabezpečený prístup. Ak je použitý prístup na základe práv, potom sa odmietajú rámce od neznámych zariadení. V zabezpečenom režime môžu zariadenia siete využit' d’alšie služby, medzi ktoré patrí:

- prístup na základe práv

- šifrovanie dát pomocou AES 128 bit

- použitie MIC (Message Integrity Code)

- odmietnutie opakujúcich sa rámcov (Sequential freshness)

Výhodou AES (Advanced Integrity Code) je, že nehrozí útok hrubou silou (t.j. vyskúšanie všetkých možných kl’účov).

MIC je kryptografický kontrolný súčet, ktorý je vložený do vysielaného rámca. Na prijímajúcej strane sa vykonáva rovnaká operácia a hodnotu súčtu porovná s prijatou. Pokial' sa správa počas prenosu zmenila, budú sa hodnoty líšit' a rámec je odmietnutý. Štruktúra protokolu ZigBee je zobrazená na obr. 3: 


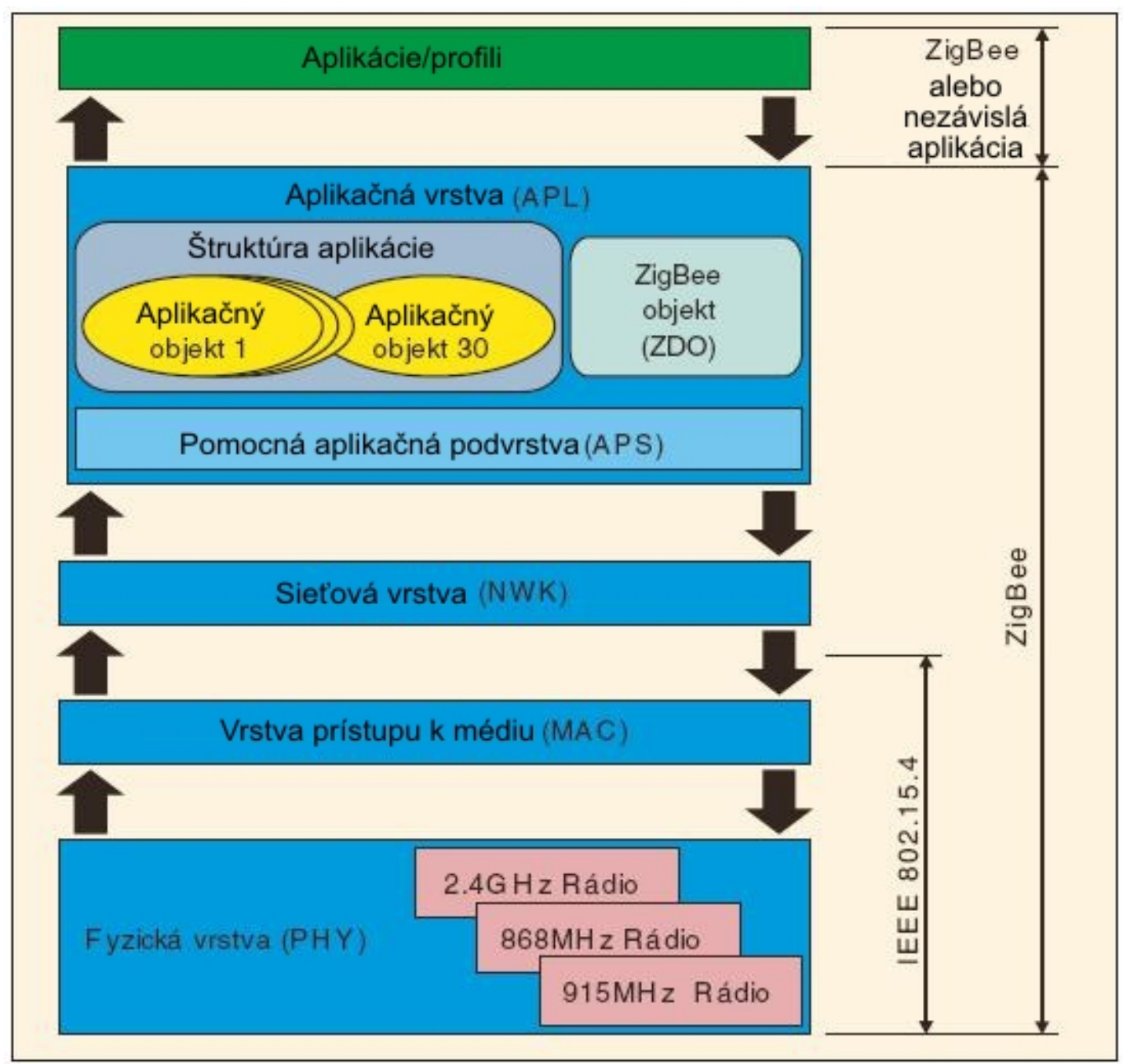

Obrázok 3 - Architektúra protokolovej štruktúry ZigBee

Je navrhnutá max. úsporne kvôli predpokladanej implementácii do málo výkonných jedno čipových 8bitových mikrokontrolórov s obmedzenými pamät’ami. Štruktúra protokolu nepresiahne viac ako $30 \mathrm{kB}$ v systémovej pamäti a je vlastne mnohonásobne úspornejší ako štandard Bluetooth, ktorý vyžaduje viac ako $100 \mathrm{kB}$ operačnej pamäte.

Nad vrstvami štandardu IEE 802.15.4 je vo vlastnom štandarde ZigBee definovaná siet'ová vrstva (NWK) a štruktúra pre aplikačnú vrstvu (APL). Siet'ová vrstva vykonáva pripájanie $\mathrm{k}$ sieti a odpájanie od nej, zabezpečenie a smerovanie paketov. Aplikačná vrstva protokolu ZigBee sa skladá z pomocnej aplikačnej podvrstvy (APS), objektov ZigBee (ZDO) a uživatel'ských aplikačných objektov. Objekt ZigBee definuje úlohu zariadenia v rámci siete ZigBee (koordinátor, smerovač alebo koncové zariadenie).

Profily ZigBee musia byt' jednoznačne určené 16bitovým identifikátorom, ktorý vydáva na žiadost' spoločnost' ZigBee Alliance. V rámci profilu ZigBee si následne tvorca aplikácie definuje deskriptory zariadenia, identifikátory správ a poskytované služby.

\section{Záver}

Moderná komunikácia M2M rozšírila spojenie bod - bod (one-to-one) do systému sietí, ktoré prenášajú dáta na osobné zariadenia. Rozšírenie bezdrôtovej siete po celom svete dalo základy pre jednoduchšiu komunikácie a zmenšila množstvo energie a času potrebného pre 
komunikáciu medzi takýmito technickým systémami. Tieto siete umožňujú rad nových obchodných príležitostí a spojení medzi napríklad spotrebitel'mi a výrobcami

\section{Literatúra}

[1] Mateides A.: Spokojnost' zákazníka a metódy jej merania, 2. diel - metódy, EPOS, Bratislava, 2000, 255 str., ISBN 80-8057-224-0

[2] KoRCHÁN T.: Aplikácia RFID v expresných službách. diplomová práca, Katedra spojov Fakulty prevádzky a ekonomiky dopravy a spojov Žilinskej univerzity v Žiline, 2009

[3] Internetové zdroje, wikipedia

\section{Grantová podpora}

- 077-059ŽU-4/2010 - Implementácia nových technológií do vzdelávania (vytvorenie RFID laboratória ako podporného prvku pre vzdelávanie)

- 1/0149/10 Difúzne procesy nových mobilných služieb a ich hodnotový ret'azec

- OPV-2009/1.2/01-SORO - Systematizácia pokrokových technológií a poznatkov medzi priemyselnou sférou a univerzitným prostredím

- 089-068ŽU-4/2010 Aplikácia RFID pri sledovaní pohybu diplomových a bakalárskych prác $\mathrm{v}$ rámci univerzitného campusu 